\title{
Students' Anxiety Levels During Online Learning During the Covid-19 Pandemic
}

\author{
Tri Dewantari ${ }^{\mathrm{a}}$, Barep Hapit Surya Putra ${ }^{\mathrm{b}}$, Siti Zahra Bulantika ${ }^{\mathrm{c}}$, \\ ${ }^{a}$ STKIP Al Islam Tunas Bangsa Bandar Lampung \\ ${ }^{\mathrm{b}}$ UIN Raden Intan Lampung \\ ${ }^{\mathrm{c}}$ STKIP PGRI Bandar Lampung \\ Email: tridewantari@stkipalitb.ac.id
}

\begin{abstract}
The Covid pandemic has a major impact on various fields, one of which is in the field of education. Currently, all sectors in the education sector are experiencing a period of adaptation in the implementation of the teaching and learning process. The teaching and learning process carried out online has several impacts, one of which is the anxiety experienced by students. The purpose of this study was to describe the level of anxiety of students during online learning during the Covid-19 pandemic in senior high school students. This research uses the descriptive qualitative method. Data analysis was performed using analysis from various scientific articles. The results showed that the level of student anxiety during online learning during the Covid-19 pandemic was different. This is due to the factors behind it, such as students' understanding of the material provided by the teacher, availability of internet network use, adequate facilities and infrastructure for taking part in online learning and the time for completing assignments which according to some students tends to be short.
\end{abstract}

\section{Keywords: Anxiety, Online Learning, Pandemic Covid-19}

\begin{abstract}
Pandemi covid berdampak besar pada berbagai bidang salah satunya yaitu pada bidang pendidikan. Saat ini seluruh sector pada bidang pendidikan sedang mengalami masa adaptasi dalam pelaksanaan proses belajar mengajar. Proses belajar mengajar yang dilakukan secara daring mengakibatkan beberapa dampak salah satunya yaitu kecemasan yang dialami siswa. Tujuan penelitian ini adalah untuk mendeksripsikan tingkat kecemasan siswa pada saat pembelajaran daring pada masa pandemic covid-19 pada siswa menengah atas. Penelitian ini menggunakan metode kualitatif deskriptif. Analisis data yang dilakukan dengan menggunakan analisis dari berbagai artikel ilmiah. Hasil penelitian menyatakan bahwa tingkat kecemasan siswa pada saat pembelajaraan daring dimasa pandemic covid-19 berbeda-beda. Hal ini dikarenakan faktor-faktor yang melatar belakanginya yaitu seperti, pemahaman siswa terhadap materi yang diberikan oleh guru, ketersediaan dalam penggunaan jaringan internet, sarana dan prasarana yang memadai dalam mengikuti pembelajaran daring dan waktu pengerjaan tugas yang menurut sebagian siswa cenderung singkat.
\end{abstract}

\section{Kata Kunci: Kecemasan, Pembelajaran Daring, Pandemi Covid-19}

\section{INTRODUCTION}

Education is an important thing for every individual. Every individual attaches importance to education, education is the best provision in every individual development (Saihu, 2020). According to the law on the National Education System, education is a conscious and planned effort to create an atmosphere of learning and the learning process so that students actively develop their potential to have religious-spiritual strength, self-control, personality, intelligence, noble character, and skills needed by themselves, the community, nation and state (Hendriana \& Jacobus, 2017).

The purpose of education will run effectively if there is good cooperation between stakeholders in the world of education, namely teachers, students, and parents of students. Cooperation between stakeholders can affect the quality of education, if there is one stakeholder who does not play its role, the goals of education will not run optimally (Damayanti, n.d.). In line with this opinion, teachers really need the involvement of parents in supporting the learning that the teacher has given to children (Pratiningsih, 2017). 
At this time the world of education is facing a transition period, the education system that is usually carried out is experiencing changes, this is due to the Covid-19 pandemic that is hitting several countries. The United Nations reports that Covid-19 has closed schools and made 1.6 billion students from 190 countries unable to carry out their usual educational activities (Suwidagdho \& Dewi, 2020). The spread of covid-19 transmission has made the Indonesian government nervous, the government is busy with various efforts to tackle the spread of the covid-19 virus. One of the efforts made by the government is making various policies carried out by the Indonesian government to tackle the spread of the covid-19 virus that has occurred. As for the countermeasures that have been carried out, such as the application of social distancing, physical distancing to the imposition of large-scale social restrictions. These regulations affect aspects of human life, one of which is in the field of Indonesian Education (Herliandry et al., 2020).

Changes that have occurred in the field of education which are the impact of covid19, namely, schools are closed, students learn online using a distance learning system, teachers prepare learning with various media that can be done online for the implementation of the teaching and learning process using online media, such as Whatsapp, Zoom Meeting, Google Meet, Youtube and various other social media (Atsani, 2020). In line with this, based on a circular from the Ministry of Education and Culture Number 36962 / MPK.A / HK / 2020 regarding online learning to prevent the spread of covid-19, namely, specifically for areas affected by covid-19 treating online learning for students and university students.

Seeing the current phenomenon in the world of education, it has resulted in several impacts, namely, teachers and students feel they have new challenges in implementing the teaching and learning process, so that the teaching and learning process continues to run optimally (Atsani, 2020). In line with this, Astini (2020) the implementation of online learning using technology, shocked teachers, students and also parents of students in carrying out learning which initially carried out face-to-face learning at this time immediately made changes online. Other research related to the impact of covid-19 on the world of education is revealed by Indrawati's research (2020) which states that some of the impacts that occurred during the Covid-19 pandemic on the world of education are the limited cost of internet pulses, academics who are not used to using online media in doing so learning, weak teaching creativity, signal interference in online lectures, and online learning saturation experienced by teachers and students. With online learning currently in several places, $34 \%$ of teachers and students complain about poor internet networks, the ability to use computers or cellphones and the internet is needed, which many students have not mastered (Cahyati \& Kusumah, 2020).

The application of online learning in education makes some students feel anxious and depressed. The number of assignments given by the teacher allows students to spend their time from morning to night working on assignments (Oktawirawan, 2020). The number of tasks given by the teacher and the pressure that occurs from the environment is one of the factors for the emergence of anxiety that occurred during the current Covid-19 pandemic (Sari et al., 2020). The pressure and the number of tasks is a factor in the anxiety experienced by students.

Based on this background, there is an interest in conducting research that aims to describe the level of anxiety of students during online learning during the Covid-19 pandemic in senior high school students.

\section{METHODS}

This research uses descriptive qualitative research methods. Descriptive qualitative research is research that provides descriptive, description and facts of the phenomena under study (Indrawati, 2020). The analysis was carried out in this study, namely the analysis of 
various scientific articles related to the level of anxiety of students during the current Covid19 pandemic. The place for library research is by using scientific articles obtained online both internationally, nationally and in various other sources.

\section{FINDINGS AND DISCUSSION Findings}

Education is an important thing in human life. Every human being needs the education to support the formation of generations who are knowledgeable, moral and able to compete in future lives (Salsabila et al., 2020). During the current covid pandemic, it was related to the learning process in accordance with a circular from the government, the learning process was carried out boldly to cope with the increasingly widespread transmission of Covid 19.

Based on this, the education process during the current Covid-19 pandemic will still run effectively even with online media. This is in accordance with what is stated in the National Education System Law Article 13 paragraph 2 which states that formal, non-formal education carried out in the education system can be done face-to-face or remotely (Indonesia, 2003). Face-to-face learning can still run effectively using existing technology systems and there is feedback between teachers, students and parents (Latip, 2020). Other research states that the use of online learning can run effectively by using preparations made by educators, namely preparing teaching materials that can attract the attention of students (Wijoyo \& Nyanasuryanadi, 2020).

\section{Discussion}

Although bold learning can be effective, the implementation of learning affects the student level. This is according to opinion (Fitria \& Ifdil, 2020) which states that the level of anxiety experienced by adolescents in the face of the current Covid-19 pandemic is due to the lack of information obtained by adolescents regarding the Covid-19 pandemic.

Anxiety is a thought that permeates the human mind that causes concern and worries in any condition that if it will occur and will cause something that is undesirable (Rahardjo et al., 2020). In line with this opinion, according to Nevid et al (2005) In line with this opinion, according to Nevid et al (2005) which states that high-intensity anxiety can interfere where individuals will feel worried and complain that something bad will happen, but anxiety does not only have a negative impact but can also have a positive impact, where anxiety can motivate individuals to do something more positive. During the Covid-19 pandemic, anxiety can be categorized into 3 categories, namely, academic stress experienced by students and students, work stress and stress in the family (Muslim, 2020).

The emergence of anxiety that has occurred to students during the online learning period during the current Covid 19 pandemic is due to students' lack of understanding of the learning material provided by the teacher, the rules of teaching and learning activities during online learning, the time for doing assignments which tends to be short so that it has the potential on decreasing student learning outcomes (Oktawirawan, 2020). The inactivity of students in the teaching and learning process can affect anxiety in undergoing online learning.

Factors that influence the emergence of student anxiety in learning during the Covid19 pandemic are emotional disturbances, competition between students, poor study habits, facilities for schools, student-teacher relationships, students are less able to adapt to existing conditions, health problems, students' wrong perspective, lack of parental guidance, authoritarian parents, parental expectations, environmental rejection, family problems and discrimination (Kartika, 2020). In line with this opinion, according to Oktawirawan (2020) namely the triggers for student anxiety during the current online learning period, namely difficulty understanding material, difficulty doing assignments, availability and conditions of 
the internet network, technical constraints, and worries about the next assignment. Another opinion states that conditions that can cause anxiety, namely deadlines for tasks to be completed, make students feel depressed (Muslim, 2020).

At this time, there are many media used by educators in carrying out learning, such as Google Classroom, Whatsapp, Smart Class, Zenius, Quipper and Microsoft Whatsapp Features (Herliandry et al., 2020). The uses of these media can be used to carry out the learning process online / online. In line with this opinion, according to Astini (2020) there are various information technology media that can be used in supporting online learning activities, namely e-learning, learning houses, Edmodo, EdLink, Moodle, Google Classroom, Schoology online class. During a pandemic, learning activities are highly dependent on technology, so teachers and students should be able to update the use of technology (Indrawati, 2020).

\section{CONCLUSION}

From the explanation above, it can be concluded that the level of anxiety of students during the Covid 19 pandemic for each student is different. This is due to the background factors, such as students' understanding of the material provided by the teacher, the availability of internet network use, adequate facilities and infrastructure in participating in online learning and the time for completing assignments which according to some students tends to be short. In anticipating students' anxiety during online learning during the Covid-19 pandemic, namely by using technology media such as google classrooms, WhatsApp groups, zoom and other online media. However, it needs to be evaluated and adjusted to existing conditions.

\section{REFERENCES}

Astini, N. K. S. (2020). Tantangan Dan Peluang Pemanfaatan Teknologi Informasi Dalam Pembelajaran Online Masa Covid-19. Cetta: Jurnal Ilmu Pendidikan, 3(2), 241-255.

Atsani, K. H. L. G. M. Z. (2020). Transformasi media pembelajaran pada masa Pandemi COVID-19. Al-Hikmah: Jurnal Studi Islam, 1(1), 82-93.

Cahyati, N., \& Kusumah, R. (2020). Peran Orang Tua Dalam Menerapkan Pembelajaran Di Rumah Saat Pandemi Covid 19. Jurnal Golden Age, 4(01), 152-159.

Damayanti, N. (n.d.). Pentingnya Kerjasama bagi Peningkatan Mutu Pendidikan.

Fitria, L., \& Ifdil, I. (2020). Kecemasan remaja pada masa pandemi Covid-19. Jurnal EDUCATIO: Jurnal Pendidikan Indonesia, 6(1), 1-4.

Hendriana, E. C., \& Jacobus, A. (2017). Implementasi pendidikan karakter di sekolah melalui keteladanan dan pembiasaan. JPDI (Jurnal Pendidikan Dasar Indonesia), 1(2), 25-29.

Herliandry, L. D., Nurhasanah, N., Suban, M. E., \& Kuswanto, H. (2020). Pembelajaran pada masa pandemi covid-19. JTP-Jurnal Teknologi Pendidikan, 22(1), 65-70.

Indonesia, P. R. (2003). Undang-undang Republik Indonesia nomor 20 tahun 2003 tentang sistem pendidikan nasional. Departemen Pendidikan Nasional.

Indrawati, B. (2020). Tantangan Dan Peluang Pendidikan Tinggi Dalam Masa Dan Pasca Pandemi Covid-19. Jurnal Kajian Ilmiah, 1(1), 39-48. 
Kartika, D. (2020). Faktor-Faktor Kecemasan Akademik Selama Pembelajaran Daring Pada Siswa SMA di Kabupaten Sarolangun. Jurnal Pendidikan Tambusai, 4(3), 3544-3549.

Latip, A. (2020). Peran literasi teknologi informasi dan komunikasi pada pembelajaran jarak jauh di masa pandemi Covid-19. EduTeach: Jurnal Edukasi Dan Teknologi Pembelajaran, 1(2), 108-116.

Muslim, M. (2020). Manajemen stress pada masa pandemi covid-19. ESENSI: Jurnal Manajemen Bisnis, 23(2), 192-201.

Nevid, J. S., Rathus, S. A., \& Green, B. (2005). Psikologi Abnormal (terjemahan). Jakarta: Erlangga.

Oktawirawan, D. H. (2020). Faktor pemicu kecemasan siswa dalam melakukan pembelajaran daring di masa pandemi covid-19. Jurnal Ilmiah Universitas Batanghari Jambi, 20(2), $541-544$.

Pratiningsih, D. (2017). Efektivitas Kerjasama Guru dan Orang Tua dalam Mendukung Pembelajaran Baca al-Quran Anak di SD IT Nurul Ishlah Banda Aceh. JURNAL ILMIAH DIDAKTIKA: Media Ilmiah Pendidikan Dan Pengajaran, 17(2), 194-209.

Rahardjo, W., Qomariyah, N., Mulyani, I., \& Andriani, I. (2020). Social media fatigue pada mahasiswa di masa pandemi COVID-19: Peran neurotisisme, kelebihan informasi, invasion of life, dan kecemasan. Jurnal Psikologi Sosial.

Saihu, S. (2020). Konsep pembaharuan pendidikan islam menurut fazlurrahman. Andragogi: Jurnal Pendidikan Islam Dan Manajemen Pendidikan Islam, 2(1), 82-95.

Salsabila, U. H., Sari, L. I., Lathif, K. H., Lestari, A. P., \& Ayuning, A. (2020). Peran Teknologi Dalam Pembelajaran Di Masa Pandemi Covid-19. Al-Mutharahah: Jurnal Penelitian Dan Kajian Sosial Keagamaan, 17(2), 188-198.

Sari, P., Bulantika, S. Z., Utami, F. P., \& Kholidin, F. I. (2020). Pengaruh Manajemen Stress dan Kelola Emosi Terhadap Tingkat Kecemasan Siswa di Masa New Normal. Bulletin of Counseling and Psychotherapy, 2(2), 62-67.

Suwidagdho, D., \& Dewi, S. P. (2020). The challenge of career guidance and counseling during the covid-19 pandemic. KONSELI: Jurnal Bimbingan Dan Konseling (EJournal), 7(2), 117-122.

Wijoyo, H., \& Nyanasuryanadi, P. (2020). Analisis Efektifitas Penerapan Kurikulum Pendidikan Sekolah Minggu Buddha Di Masa Pandemi COVID-19. JP3M: Jurnal Pendidikan, Pembelajaran Dan Pemberdayaan Masyarakat, 2(2), 166-174. 